\title{
Increasing Life Span of Government Housings of Chandigarh - A Need-Based Approach to Retrofit Through Prototype Study of E-Type Housing
}

\author{
PREETI PAHWA ${ }^{1 *}$ AND ANISH SHARMA ${ }^{2}$ \\ ${ }^{1 *}$ Associate Professor, Chitkara School of Planning and Architecture, Chitkara \\ University Punjab, India \\ ${ }^{2}$ Anish Sharma Design Studio, \#1487, Pushpac Complex, Sector 49B, Chandigarh, \\ India
}

\section{Email: preeti.pahwa@chitkara.edu.in}

Received: February 18, 2016 l Revised: March 14, 2016l Accepted: June 08, 2016

Published online: July 04,2016

The Author(s) 2016. This article is published with open access at www.chitkara.edu.in/publications

\begin{abstract}
This paper describes a project undertaken by the authors during their post-graduate studies at the University of Sheffield. The intent of the project was to identify building(s) that need up-gradation/retrofit, establish why retrofit is required, what kind of retrofit is needed and which techniques to employ, using a case-sensitive approach. However, the scope of this paper is limited to the first two objectives of the project and the recognition of retrofit techniques is left open-ended, so as to leave room for future debates and deliberations.

The city of Chandigarh has always been highlight prominently on India's architectural heritage map. Various buildings designed by Le Corbusier and his team (comprising Pierre Jeanerette, Jane Drew and Maxwell Fry) are like jewels (to be treasured) on this map. Still, ever since these buildings, especially the government housings, came into existence, no systematic procedures have been undertaken to analyse and assess their deterioration with time and usage. Passing down the streets of Chandigarh, one would observe how drastically the housings have been modified, and in some cases, have lost their original appeal.

The paper is essentially drafted in three parts. The first part illustrates the conditions and political background in which these buildings were designed, so as to better understand the essence of this architecture. The second part tries to comprehend the current state of one of the many types of the Government Housings present in Chandigarh - the 'House Type E1' in Panjab University. Lastly, the authors use various scales, like present seismic byelaws and Computer Aided simulation tools, to evaluate how the given housing now fares in terms of structural stability and thermal \& visual comfort.
\end{abstract}

Keywords: Retrofit, case-sensitive, Chandigarh, Housing, Government Housing, Pierre Jeanerret, Jane drew, Maxwell Fry, Simulation, Computer-aided, Energy, Seismic scale, Thermal comfort, Visual comfort.
Creative Space (CS)

Vol-4, No-1

July 2016

pp. $67-86$

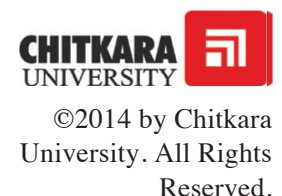


Pahwa, P Sharma, A

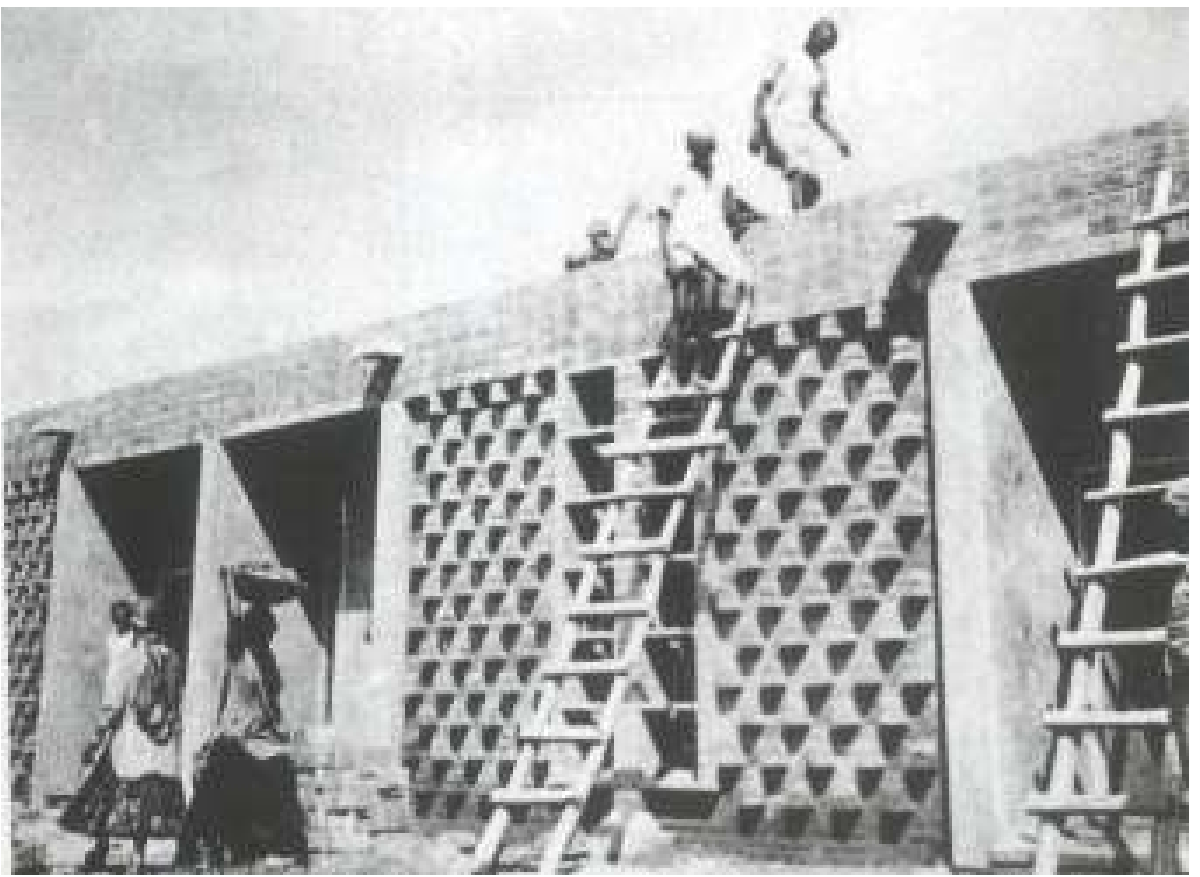

\section{INTRODUCTION}

Chandigarh, the 'City Beautiful', was conceived as a modern city in the newly independent India. A big chunk of the original architecture in Chandigarh is constituted by the Government Housings built during the 1950s and 1960s. Although, these housings were designed with utmost care, keeping in mind the climate and the monetary conditions of the state, they have served well to this day as protective shelters for the people in the composite climate of the region. Also, one might note that Chandigarh lies in the Zone 4 of seismic vulnerability. As the social setup of India has changed largely, it being the fastest growing economies of the world, the needs of the users, as they get more and more exposed to the western world, have also changed.

Fifty years is a long tenure for such large scale projects to survive the test of time and climate. Now, a time has come when these buildings, which form the bulk of the modern heritage of Chandigarh, need to be retrofitted and upgraded to suit the needs of the people and the fast changing climate so that they are suitable to live in for, at least, the next 40-50 years. Also, the idea of retrofitting stands strongly in favour of sustainable practices since the carbon footprint of a building is decreased by making most use of the embedded energy and also makes them structurally stable. 


\section{DESIGN PHILOSOPHY AND SIGNIFICANCE OF GOVERNMENT HOUSINGS OF CHANDIGARH}

Although Chandigarh is indebted to Le Corbusier for the planning and designing of the large scale government buildings that lend the city a character of sculptural monumentality; the city's urban character evolved mainly because of the modest architecture of the Government housings. The credit for this goes to Pierre Jeanneret who, along with his colleagues Maxwell Fry and Jane Drew, was responsible for much of Chandigarh's civic architecture.

Despite excellent examples of traditional palaces and havelis of various typologies in the vast hoary cultures of the Indian sub-continent, there was no well-defined model for architecture for 'modern' homes which its nascent modern society needed. Moreover, these new model had to be functional in purpose and acceptable to the people living in it.

"Taking Chandigarh as an example, we may see at once the democratic idea which allows us to devote an equal care to housing all classes of society, to seek new social groupings, new patterns of education and public welfare, and made more possible by practical application of the scientific idea which, through industrialism, gives us such benefits as piped water, electricity, cheap transport and the like. It so happens, that Chandigarh is remote from industrial centers, and that a fair proportion of its population follow traditions and customs at variance with these ruling ideas, but because it is a function of the architect to interpret change in terms of planning and building, to this extent his work is educative, molding life by creating new forms for it, and maybe therefore be in advance of its time."-Maxwell Fry [4]

Three major disciplines governed the design of these housings:

\subsection{The Discipline of Climate}

Chandigarh has extreme weather conditions the year round. Winters temperature near the freezing point, summer months are hot-dry or hot-wet. The monthly distribution of weather conditions is quite balanced: four months of winter six months of summer and about two months of pleasant weather. Thus, it becomes quite important to design buildings that would cater to the comfort throughout the year. In such climatic conditions, sun was considered an enemy more often than a friend. As such, the architectural issues were: First to make shade, second to make current of air (to ventilate), third to control hydraulics (to evacuate rain water). Much attention was paid to creation of cool interiors, adequately protected from the southwest sun but within a limited budget [1].
Increasing

Life Span of

Government

Housings of

Chandigarh - A

Need-Based

Approach to Retrofit Through Prototype Study of

E-Type Housing 
Pahwa, P

Sharma, A

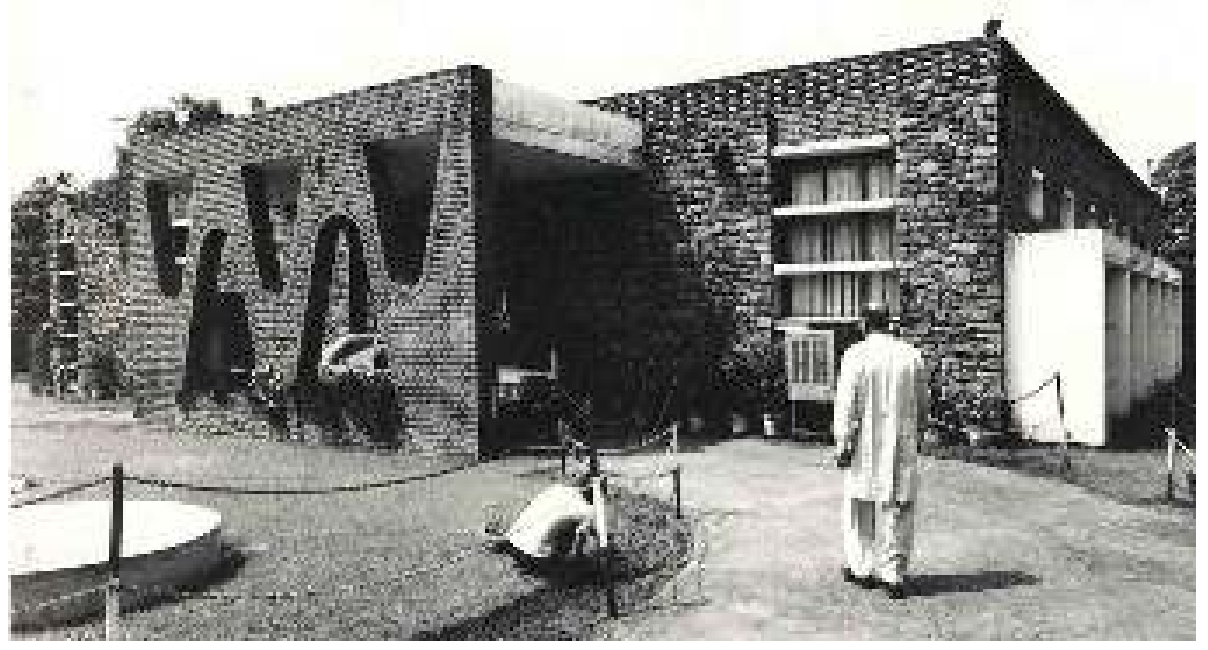

Figure 1 (Previous page): Some of the smallest houses designed by Pierre Jeanneret. Projecting bricks animated the simple facades while shadows cast by the projections helped to lower temperatures.

Figure 2 (Above): Ministers' Houses, Sector 2, Chandigarh. Even the largest of the Government Housings followed the disciplines of Climate, Technoogy and Money

(Image Source: Joshi, Kiran, (1999) Documenting Chandigarh-The Indian Architecture of Pierre Jeanneret, E. Maxwell Fry, Jane B. Drew. Ahmedabad: Mapin Publications

\subsection{The Discipline of Technology}

We are making in India great things with hand labour, without machines; architecture abounds there; it flows as the music flows in Johann Sebastian Bach, because it is built on a foundation, on a texture. There is a material and intellectual armature which makes everything develop in dazzling fashion. Money has nothing to do with a man of feeling. It is a good thing for an architect to have little money," - Jane Drew [4]

The scarcity of steel in India made steel-frame construction impossible. Even reinforcement was so expensive that it was largely employed only in large and important buildings. Seasoned wood being expensive, in much of the housing, brick was used for shelves, etc. However, large quantities of building material required to make good quality bricks and human labour were readily available. So in Chandigarh, reliance on local materials was an important parameter when it came to choosing the building materials for the housings (Fig. 2). The materials from which the housings in Chandigarh were constructed were concrete and locally manufactured brick. Concrete, considered as a poor material in the West, was treated here as noble [2]. 


\subsection{The Discipline of Money}

Le Corbusier once remarked that,

India has the treasures of a proud culture; but her coffers are empty and throughout the project the desire for grandness was hampered by the need for strict economy [8].

The procedure for imposing budgetary restrictions on designs, according to Le Corbusier, was as follows:

The budget for the construction of the city has been established by the Administrator and the Chief Engineer in an impeccable manner. It consists of an enormous mimeographed volume containing an explanation of the total expenditures to be engaged, and consequently everything to be constructed. Everything, street, palace or house betokens a rigorous program, detailed piece by piece with the exact dimensions required for each element and the application of the various prices of different coefficients [6].

The budgetary constraints being a major determinant, design of every unit and all the details were evolved to fulfil the requirements without going overbudget. Jeanneret, Fry and Drew did pioneering work in the evolution of these designs which were down-to-earth, innovatively minimal and merged quite well with the idea of Chandigarh. The use of brick as the main construction material proved to be a wise decision towards addressing the low-cost character. Another step towards reducing construction costa was reduction of sizes of windows and not installing larger and expensive glass panes and also decreasing the size of concrete lintels over the windows.

\section{THE SUCCESS OF THE HOUSINGS}

The overall visual expression of these housings was thus governed by exposed or plastered brick, inferior grade bricks being plastered and superior grade bricks being exposed. The quality of brick being cut into various shapes and sizes was fully exploited by Jeanneret and his colleagues to construct parapets, jallis, sun breakers, fireplaces, chimneys, niches, projections and, sometimes, even murals on the exteriors.

A major deviation from the traditional houses was the elimination of verandahs. Jeanneret considered them to be an expensive solution to tackle the problems of climate. So he introduced canopies and vertical fins to protect walls and openings from the sun and rain. Projecting bricks on outer walls was an elevational feature employed to reduce the amount of heat that could be
Increasing

Life Span of

Government

Housings of

Chandigarh - A

Need-Based

Approach to Retrofit Through Prototype Study of

E-Type Housing 
Pahwa, P Sharma, A

gained by the relatively low thermal massed bricks. Standardization of sizes of RCC battens, doors and windows facilitated mass production on construction sites, which helped in economising manufacturing and installing [1]. The sheer volume and quality of housing was instrumental in deciding the exclusive profile of the city and delineating their impact on the lifestyles of the people.

\section{THE CURRENT SCENARIO}

Due to constant wear and tear of these buildings during the last 50 years, the performance of the original insulation has gone down. The present occupants have modified the internal layouts and the facades in order to retrofit these in their own fashion. Also, as the socio-cultural setup of urban India has changed significantly, there is a need to upgrade these housings to suit the ever increasing living standards of their residents. For example, the width of most of the staircases in two or multi-storeyed housings were just kept nominal to accommodate one or two persons climbing them. But now, Chandigarh being the city with highest per capita income, the basic needs of people to buy a refrigerator or a dish-washer faces problems since they find it difficult to transport them to their homes on the upper floors. Similarly, insufficient car parking spaces, increased electrical loads (thereby rendering the existing wiring redundant) and, the need for bigger water supply pipes to support the new-age shower systems, etc., comprise some items on the list that showcases retrofitting needs. The above problems indicate clearly that the architects need to be very sensitive while identifying the root causes to upgrade these housings and very meticulously devise design solutions to retrofit them and make them energy efficient.

\section{THE RESEARCH QUESTION}

Since the main aim of this paper is to look at the present structural and environmental condition of the housing under consideration, and thus identify the basis for carrying out retrofit processes, a step by step procedure is followed for assessing the kind of retrofit required and its successful application to the existing structure. Based on this idea, and the background information that has been provided previously, the research question was formulated as:

To analyse the kind/extent of retrofit that would be required to revitalize the housings structurally and environmentally.

5.1 Before any interventions can be made to increase the load-bearing capacity of a structure, it is pertinent to appraise its existing strength. Since the loadbearing capacity of a structure does not depend only on the structural layout and 


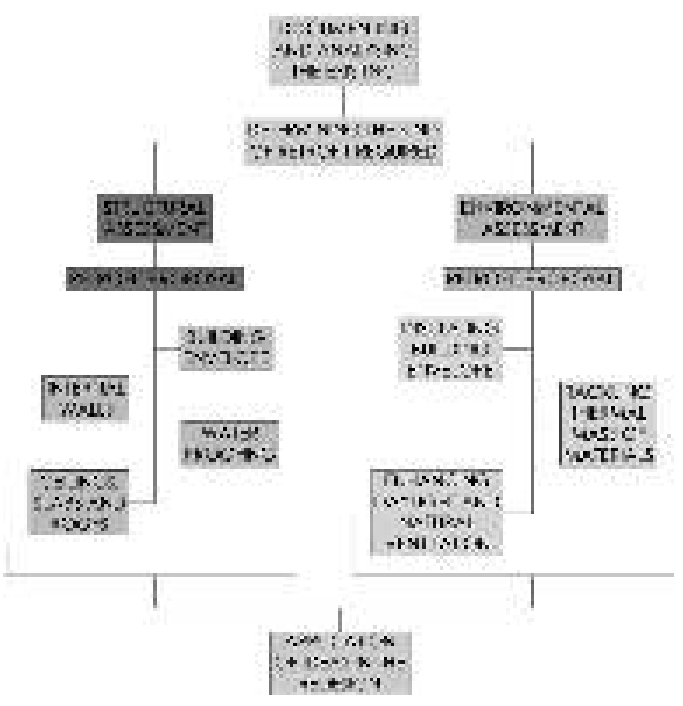

Figure 3: Flowchart showing methodology for carrying out the retrofit of House Type E-1.
Increasing

Life Span of

Government

Housings of

Chandigarh - A

Need-Based

Approach to

Retrofit Through

Prototype Study of

E-Type Housing

mechanical properties of materials, but also on possible hidden errors and damage caused by previous events such as earthquakes, the assessment procedure gets complex. The process for checking seismic stability of structures takes place in multi-levels -- visually examining the building, during which the data about the structural system is gathered and possible errors in structural layout, construction and maintenance are identified. The cexamination also identifies the weak joints and cracks [7]. This yields a qualitative data of the existing conditions, which further forms the basis of determining the required structural intervention. To put things in the right perspective, the scope of structural retrofit is limited, based on the visual observations made at site and not quantitative analysis, i.e., taking physical measurements for seismic stability on site.

5.2 Environmentally, analysis needs to be done about the performance of the building, both in terms of daylighting levels and the thermal comfort levels, so as to find out the extent to which the building needs to be retrofitted to increase its responsiveness to the climate of Chandigarh.

5.3 After undergoing these processes, at a later stage, all the information can be consolidated and these would form guidelines of retrofitting one housing unit. Both the structural and environmental assessment information would come together and be reflected in the redesign proposal of the unit under scrutiny. This methodology of carrying out the holistic retrofit of House Type E-1 has been interpreted in the form of a flow chart shown in Fig. 3. 
Pahwa, P

Sharma, A

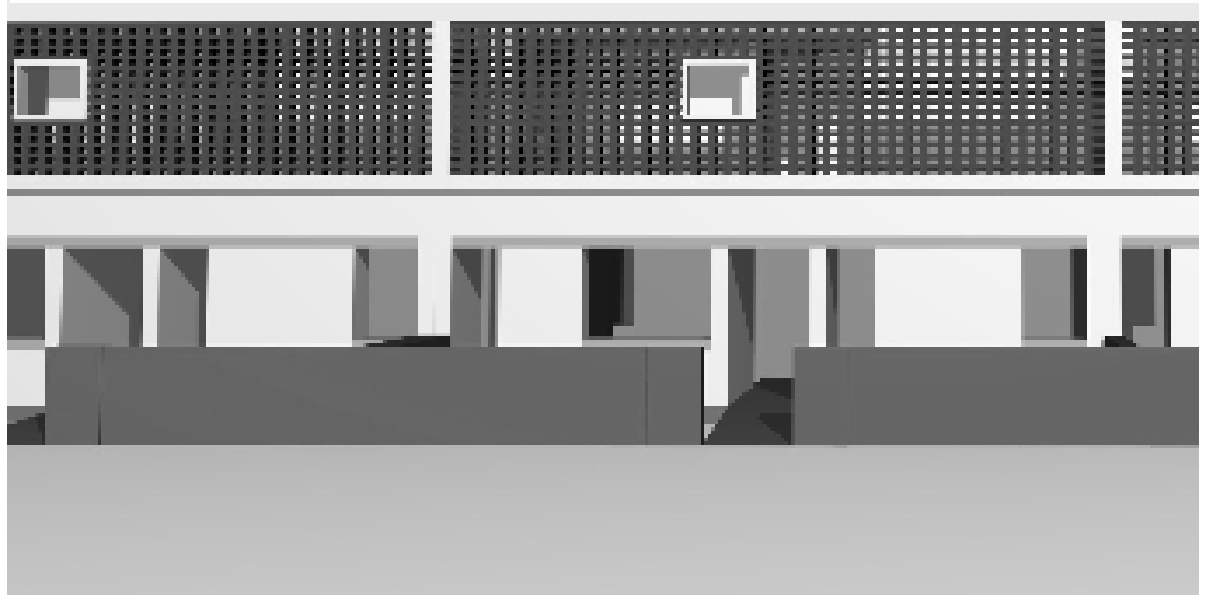

Figure 4: Different shots of digitally modeled existing housing units showing the continuous brick screen facade and material definitions.

\section{THE E-1 TYPE HOUSING}

This housing is located in the campus of Panjab University in Chandigarh. It is an attached row housing, with each house designed as a duplex unit.

The site layout by Jeanneret, consists of back-to-back units arranged in a linear fashion. The orientation of most of the houses is northeast to southwest. The singular access to the spaces inside the house is through a corridor. The ground floor comprises of a drawing room which is attached to the dining area. On the other side of the corridor is a bedroom. The convenience to use the bedroom gets enhanced for users due to its location on the ground floor. Towards the back of the central stairwell are the kitchen, a small store and a bathroom. The first floor comprises two bedrooms which are attached to a screened outdoor sleeping terrace, which is socially quite acceptable to people keeping in view the climate of Chandigarh and the shared light that comes into these rooms. The bedrooms share a common toilet.

External facades are simple compositions of brick screens and plastered, lime washed surfaces. The brick screen, running all along the terraces, is a binding element imparting a singular identity to these houses. The regularly occurring square openings within the screens form interesting composition. The windows are recessed, as is the case with all the housings in the city. This is a way of providing sun shades to the openings by not investing too much in making the lintels and also giving a definite character [5]. (Figs. $4,5 \& 6$ ) 

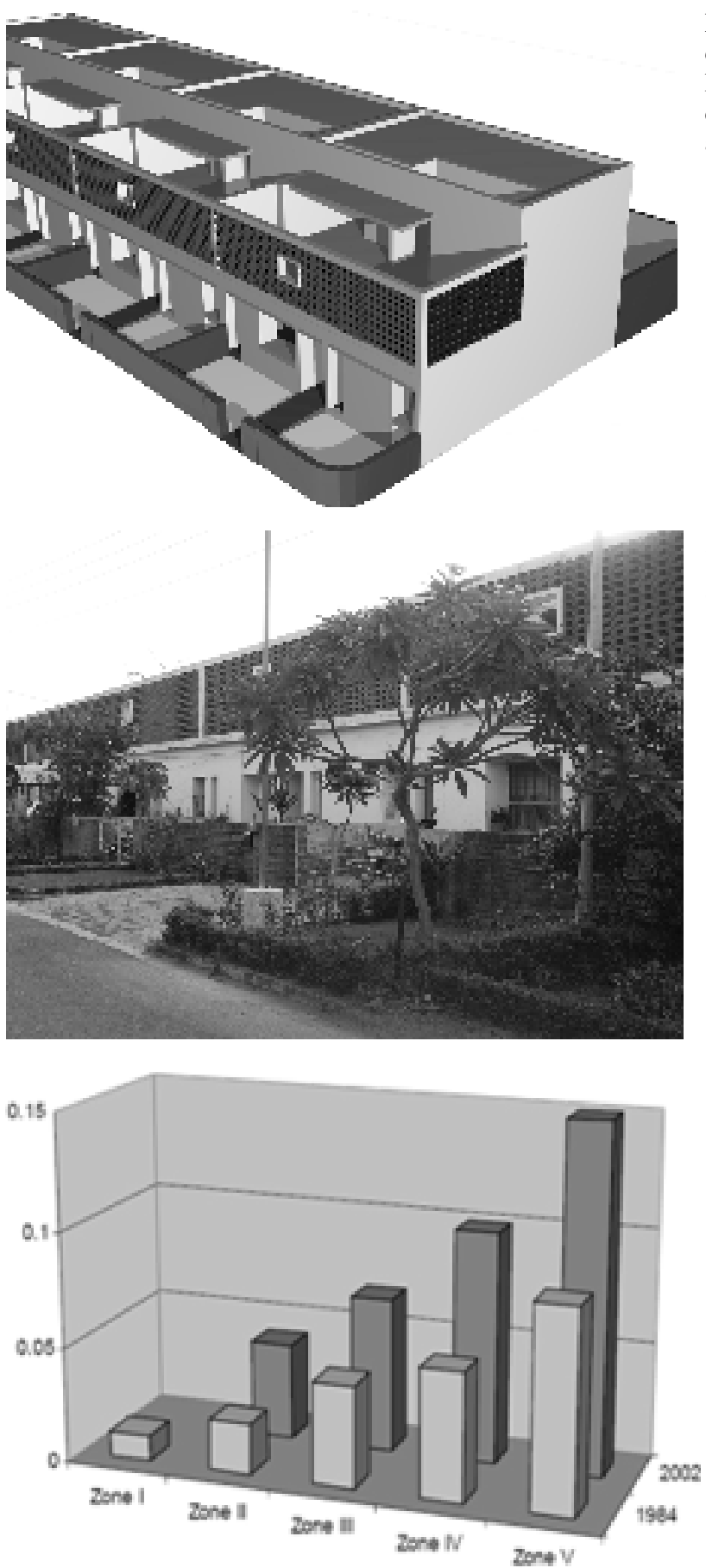

Figure 5: Different shots of digitally modeled existing housing units showing the continuous brick screen facade and material definitions.

Figure 6: Photo showing the continuous facade of House Type E-1.

Figure 7: Variations of seismic coefficient as per IS 1893: 1984 and IS 1893: 2002.
Increasing Life Span of Government Housings of Chandigarh - A Need-Based

Approach to Retrofit Through Prototype Study of E-Type Housing 
Pahwa, P

Sharma, A

\subsection{Critical Overview of the Housing}

\subsubsection{Structural Problems faced by the Housing}

For taking a look at the seismic vulnerability of Chandigarh, one starts with the seismic coefficients in the country. Earlier there were 5 seismic zones in India, Zone 1 being the least and Zone 5 being the most prone to earthquakes. Zone 1 has now been merged with Zone 2, and only 4 seismic zones coexist, with Zone 4 being the most prone to earthquakes. For Chandigarh, the "Basic Horizontal Seismic Coefficient" used to be 0.05, but now is 0.24 [3]. The city lies in Zone 4 now and, is more prone to earthquakes high on Richter scale. The seismic vulnerability of old masonry buildings is typically very high because of their load-bearing construction aimed at resisting vertical loads [7]. Hence, building code requirements for seismic lateral forces are understood to have increased by more than $100 \%$ in Chandigarh. Since the average life of buildings in Chandigarh is about 50 years, it implies that these housings, constructed in around 1960s, are quite vulnerable to moderate or strong earthquakes.

Structural interventions are also required for rearrangement of living spaces for better current utility and, improving design features (Fig. 7). A visual survey of 5 of the E-1 type houses reveals some common structural faults (Figs. 8, 9, 10, $11 \& 12$ ). Cracks/fissures are seen at joints of two materials, i.e., brick and concrete; water is seeping through these fissures and creating further problems and, at places, one can see the reinforcement bars rusting and rotting.

\subsubsection{Environmental Problems in the Housing}

The change in global climatic conditions coupled with incompetent environmental retrofit techniques for treatment of the building skin, have rendered these housings to become "energy inefficient" when it comes to total protection from the natural elements. To calculate the exact building performance and to determine the retrofit techniques which the building demands, some environmental simulations have been carried out.

Table 1: Table showing the climate data of Chandigarh.

\begin{tabular}{lllllllllllll}
\hline Month & Jan & Feb & Mar & Apr & May & Jun & Jul & Aug & Sep & Oct & Nov & Dec \\
\hline $\begin{array}{l}\text { Mean min. temp } \\
\left({ }^{\circ} \mathrm{C}\right)\end{array}$ & 6 & 8 & 13 & 19 & 23 & 24 & 25 & 23 & 22 & 17 & 11 & 7 \\
$\begin{array}{l}\text { Mean max. temp } \\
\left({ }^{\circ} \mathrm{C}\right)\end{array}$ & 20 & 23 & 28 & 35 & 38 & 40 & 36 & 33 & 32 & 31 & 27 & 22 \\
$\begin{array}{l}\text { Precipitation } \\
(\mathrm{mm})\end{array}$ & 58 & 43 & 43 & 16 & 26 & 125 & 280 & 308 & 174 & 28 & 11 & 21 \\
$\begin{array}{l}\text { Average wind } \\
\text { speed }\end{array}$ & 6.86 & 6.78 & 6.61 & 6.47 & 6.92 & 6.89 & 5.22 & 4.76 & 5.39 & 6.44 & 7.02 & 7.16 \\
\hline
\end{tabular}



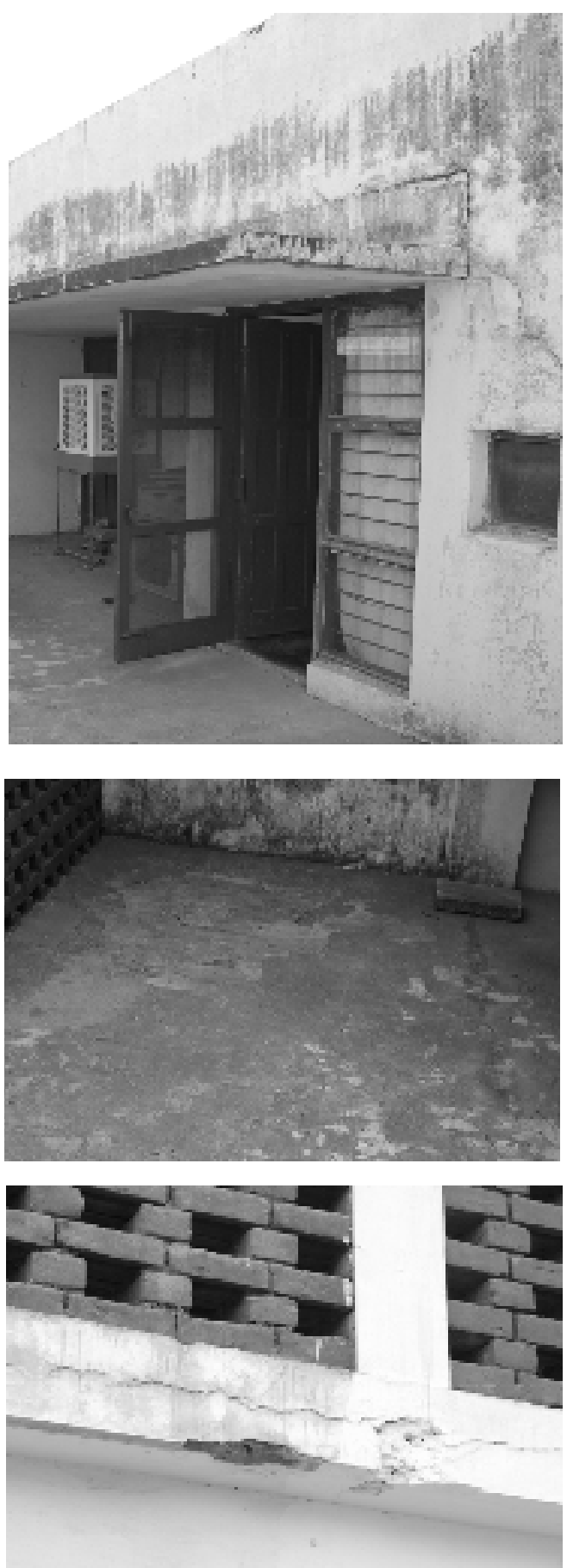

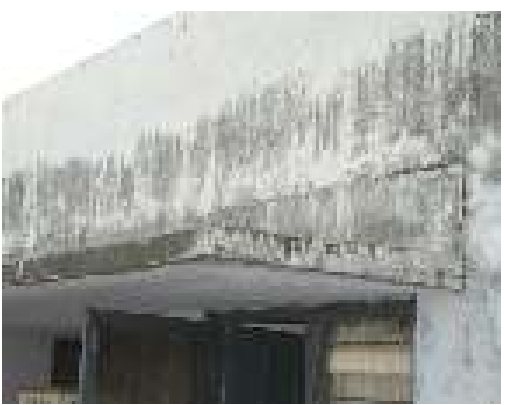

Increasing Life Span of Government Housings of Chandigarh - A

Need-Based

Approach to Retrofit Through Prototype Study of E-Type Housing

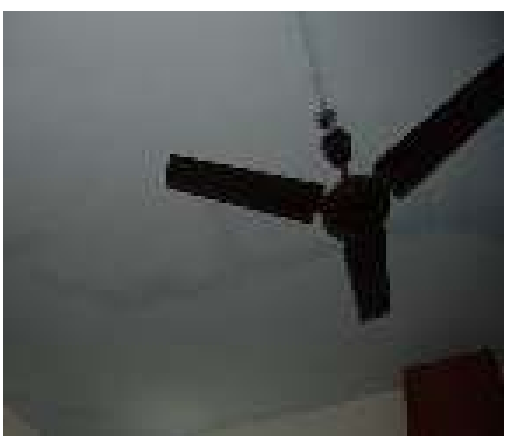

Figure 8 (Top Left): Development of cracks is evident where different building materials meet.

Figure 9 (Top Right): Development of cracks is evident where different building materials meet.

Figure 10 (Above): Structural faults identified in the ceiling slabs.

Figure 11 (Left): Water seeps in to the structure, rendering it weak at intersections of different structural planes.

Figure 13 (Bottom Left): Rusted and weathered reinforcement can be seen wherever concrete cover has come off. 
Pahwa, P

Sharma, A

\subsubsection{Daylight Analysis of an Existing Housing Unit}

The natural lighting levels that were calculated in Ecotect Daylighting Analysis and, the results so obtained, represent worst-case design conditions based on an 'average' cloudy or uniform sky distribution. The lighting levels determined in this case calculate daylight factors using the sky, external and internally reflected components, along with the design sky luminance. All the grid nodes over the analysis grid were assumed to be on a horizontal surface with a vector pointing directly upwards. This value is $600 \mathrm{~mm}$ above the finished floor level, which is usually the height of a working plane. The Sky Luminance value is the horizontal luminance that is exceeded $85 \%$ of the time between 9am and $5 \mathrm{pm}$ throughout the working year. In the case under scrutiny, using the Tregenza Formula (built into the software) and the current latitude of the site $\left(76.78^{\circ} \mathrm{E}\right)$, the value comes out to be 8755 lux.

Room Based Settings to calculate daylight factors are based on two factors; the size and location of windows and the reflectivity of internal surfaces. Windows' cleanliness is based on the fact that windows, over a period of time, tend to accumulate dirt. The cleanliness factor here has been taken as average which corresponds to reduction in transmittance. The internal reflections depend on the ratio of the window openings to the overall surface area in each room. So, the Room-Averaged Windows Areas have been calculated so that some areas which do not see any windows may report zero daylight factors.

Finally, Increased Accuracy Mode was switched on while calculating the lighting levels so as to get as precise results as possible. This mode takes into account transparency and refractive index of window glazing and actual surface reflectance of external obstructions instead of standard values. (Figs. 13, 14 \& 15)

The daylight analysis of the ground floor shows that the average Lux levels inside the building are about 180 Lux, which can hardly be considered satisfactory . According to the National Building Code of India - 2005, the required lighting levels inside a residential building are as given in Table 2 below:

Table 2: Required lighting levels inside residential buildings as per NBC, 2005.

\begin{tabular}{lll}
\hline $\begin{array}{l}\text { Average Daylight } \\
\text { levels }\end{array}$ & Appearance & Energy implications \\
\hline <250 Lux & Room looks gloomy & Electric lighting needed most of the day \\
$\mathbf{2 5 0}$ Lux to 400 Lux & $\begin{array}{l}\text { Predominantly daylit appearance, but } \\
\text { supplementary artificial lighting needed. }\end{array}$ & $\begin{array}{l}\text { Good balance between lighting and } \\
\text { thermal aspects }\end{array}$ \\
>400 lux & Room appears strongly day lit & $\begin{array}{l}\text { Daytime artificial lighting rarely } \\
\text { needed, but potential for thermal } \\
\text { problems due to overheating in summer } \\
\text { and heat losses in winter }\end{array}$ \\
\hline
\end{tabular}




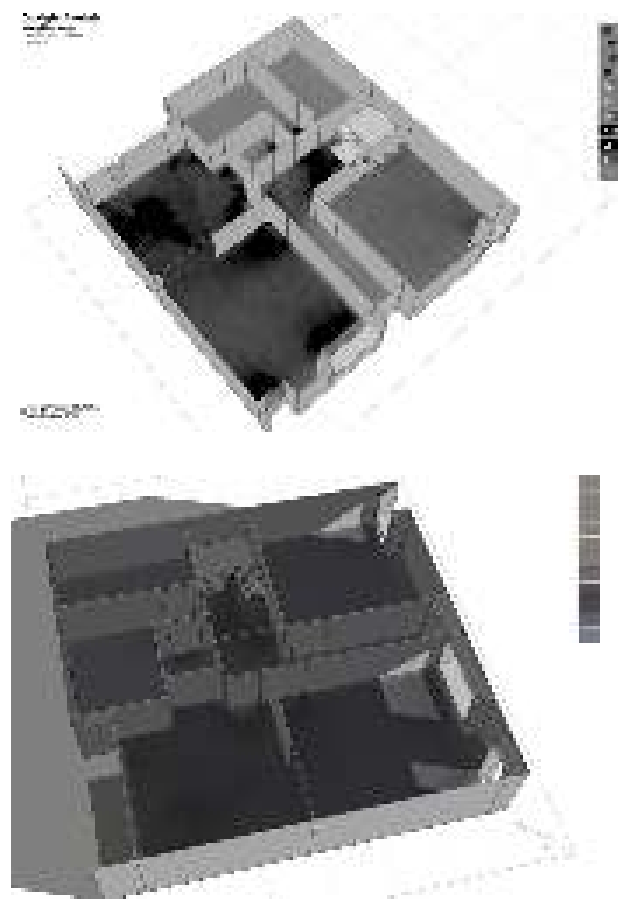

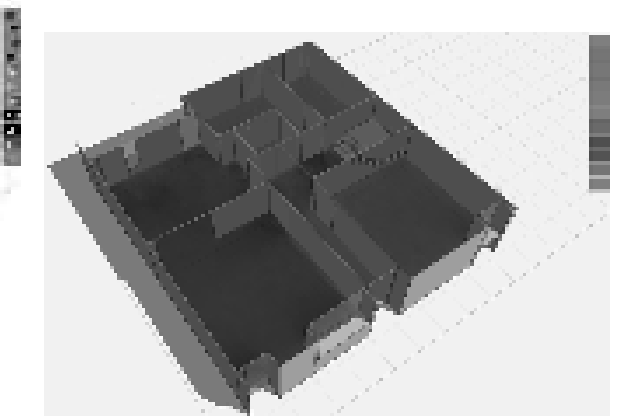

Figure 13 (Above Left): Graphic showing the Daylight Analysis of the Existing Ground Floor

Figure 14 (above Right): Graphic showing the Shadow Pattern of the Existing Ground Floor at 11.00 am on June 15.

Figure 15 (Left): Graphic showing the Shadow Pattern of the Existing Ground Floor at 11.00 am on January 08 .

It is worthwhile to mention that there are specific areas like the bedroom, kitchen and toilet, the lighting levels of which fall to as low as just 1 Lux. The data interprets that lights have to be kept turned on all the time in these spaces, which leads to massive increase in energy consumption of the house. These, then will be high priority areas where the redesign strategies will be needed for improving natural light and ventilation conditions.

The figure which shows the pattern of shadows cast by external walls, indicates that direct sun-rays fall in the bedroom only early in morning, where as the space is primarily used during evenings and the night. Hence, it will not be wrong to conclude that either its position should be shifted to where sun's warmth reaches the external walls after the noon time or some passive techniques, like erection of a Trombe wall, should be adopted to delay the release of solar heat into the room in evening (Figs. 16, $17 \& 18$ ).

An interesting result was observed during the analysis of the First Floor, which is that it is much better naturally lit with average lighting levels of 300 Lux. This floor, thus, does not require much intervention in terms of daylight improvement and can be passed as 'good'. 
Pahwa, P

Sharma, A
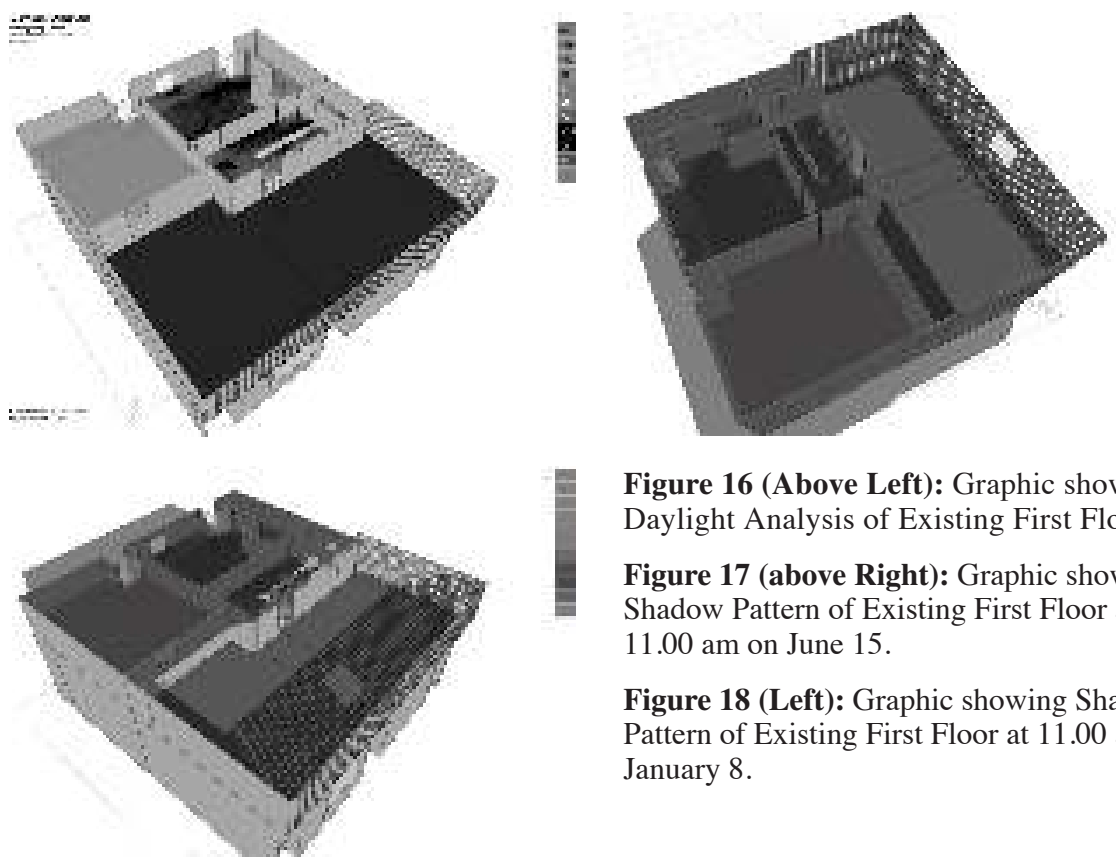

Figure 16 (Above Left): Graphic showing Daylight Analysis of Existing First Floor.

Figure 17 (above Right): Graphic showing Shadow Pattern of Existing First Floor at 11.00 am on June 15 .

Figure 18 (Left): Graphic showing Shadow Pattern of Existing First Floor at 11.00 am on January 8 .

\subsubsection{Thermal Analysis of the Residence}

For Thermal Analysis, materials specifications of the different building elements used are shown in Tables 3 - 8:

Table 3: Walls - Brick Plastered (Fig. 19), U-value:2.260W/m².K.

\begin{tabular}{llllll}
\hline $\begin{array}{l}\text { Sr } \\
\text { No. }\end{array}$ & Layer name & $\begin{array}{l}\text { Width } \\
(\mathbf{m m})\end{array}$ & $\begin{array}{l}\text { Density } \\
\left(\mathbf{k g} / \mathbf{m}^{\mathbf{3}}\right)\end{array}$ & $\begin{array}{l}\text { Specific Heat } \\
(\mathbf{J} / \mathbf{k g . K})\end{array}$ & $\begin{array}{l}\text { Thermal Conductivity } \\
(\mathbf{W} / \mathbf{m} . \mathbf{K})\end{array}$ \\
\hline 1 & Plaster (Moulded Dry) & 10 & 1250 & 1088 & 0.431 \\
2 & Brick Masonry & 110 & 2000 & 836.8 & 0.711 \\
3 & Plaster (Moulded Dry) & 10 & 1250 & 1088 & 0.431 \\
\hline
\end{tabular}

Table 4: Ceiling - Suspended Concrete Ceiling (Fig. 20), U-value:3.000W/m².K.

\begin{tabular}{llllll}
\hline $\begin{array}{l}\text { Sr. } \\
\text { No. }\end{array}$ & Layer name & $\begin{array}{l}\text { Width } \\
(\mathbf{m m})\end{array}$ & $\begin{array}{l}\text { Density } \\
\left(\mathbf{k g} / \mathbf{m}^{3}\right)\end{array}$ & $\begin{array}{l}\text { Specific Heat }(\mathbf{J} / \\
\mathbf{k g . K})\end{array}$ & $\begin{array}{l}\text { Thermal Conductivity } \\
(\mathbf{W} / \mathbf{m} . \mathbf{K})\end{array}$ \\
\hline 1. & Plaster (Moulded Dry) & 10 & 1250 & 1088 & 0.431 \\
2. & Brick Masonry & 110 & 2000 & 836.8 & 0.711 \\
3. & Plaster (Moulded Dry) & 10 & 1250 & 1088 & 0.431 \\
\hline
\end{tabular}




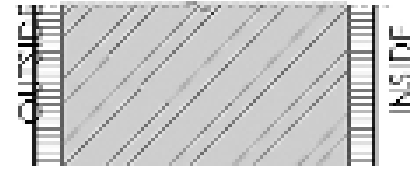

Figure 19: Thermal analysis - Wall: Plastered brick wall.

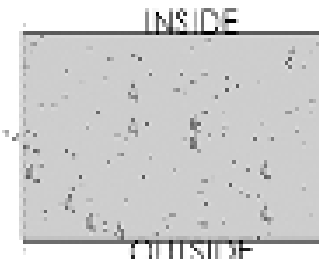

Figure 22: Thermal analysis - Floor: Concrete Floor Suspended.
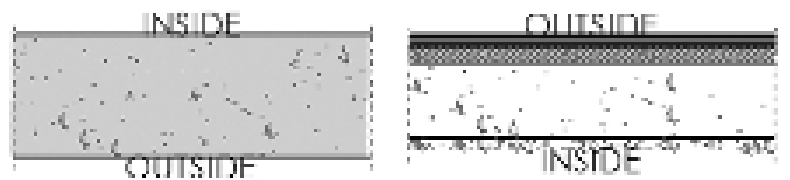

Figure 20: Thermal analysis - Figure 21: Thermal analysis Suspended Concrete Ceiling. Roof: Concrete \&Brick Tiles.

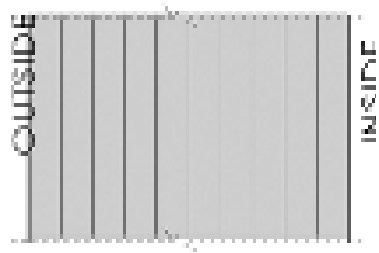

Figure 23: Thermal analysis - Windows: Single Glazed Timber Framed.
Increasing Life Span of Government Housings of Chandigarh - A

Need-Based

Approach to Retrofit Through Prototype Study of E-Type Housing

Table 5: Roof - Concrete Roof brick tiles (Fig. 21), U-value:1.030W/m².K

\begin{tabular}{llllll}
\hline $\begin{array}{l}\text { Sr. } \\
\text { No. }\end{array}$ & Layer name & $\begin{array}{l}\text { Width } \\
(\mathbf{m m})\end{array}$ & $\begin{array}{l}\text { Density } \\
(\mathbf{k g} / \mathbf{m 3})\end{array}$ & $\begin{array}{l}\text { Specific Heat }(\mathbf{J} / \\
\mathbf{k g . K})\end{array}$ & $\begin{array}{l}\text { Thermal Conductivity } \\
(\mathbf{W} / \mathbf{m} . \mathbf{K})\end{array}$ \\
\hline 1 & Plaster (Moulded Dry) & 10 & 1250 & 1088 & 0.431 \\
2 & Brick Tile & 15.9 & 2403 & 900 & 0.690 \\
3 & Lightweight Concrete & 150 & 950 & 656.9 & 0.209 \\
4 & Plaster Ceiling Tiles10 & 1120 & 840 & 0.380 & \\
\hline
\end{tabular}

Table 6: Floor - Concrete Floor Suspended (Fig. 22), U-value: $3.000 \mathrm{~W} / \mathrm{m}^{2}$.K.

\begin{tabular}{llllll}
\hline $\begin{array}{l}\text { Sr. } \\
\text { No. }\end{array}$ & Layer name & $\begin{array}{l}\text { Width } \\
(\mathbf{m m})\end{array}$ & $\begin{array}{l}\text { Density } \\
(\mathbf{k g} / \mathbf{m 3})\end{array}$ & $\begin{array}{l}\text { Specific Heat }(\mathbf{J} / \\
\mathbf{k g . K})\end{array}$ & $\begin{array}{l}\text { Thermal Conductivity } \\
(\mathbf{W} / \mathbf{m} . \mathbf{K})\end{array}$ \\
\hline 1 & Concrete & 150 & 3800 & 656.9 & 0.753 \\
\hline
\end{tabular}

Table 7: Windows:Single Glazed Timber framed (Fig. 23), U-value: $5.100 \mathrm{~W} / \mathrm{m}^{2} . \mathrm{K}$

\begin{tabular}{llllll}
\hline $\begin{array}{l}\text { Sr. } \\
\text { No. }\end{array}$ & Layer name & $\begin{array}{l}\text { Width } \\
(\mathbf{m m})\end{array}$ & $\begin{array}{l}\text { Density } \\
\left(\mathbf{k g} / \mathbf{m}^{\mathbf{3}}\right)\end{array}$ & $\begin{array}{l}\text { Specific Heat }(\mathbf{J} / \\
\mathbf{k g . K})\end{array}$ & $\begin{array}{l}\text { Thermal Conductivity } \\
(\mathbf{W} / \mathbf{m} . \mathbf{K})\end{array}$ \\
\hline 1 & $\begin{array}{l}\text { Glass } \\
\text { Standard }\end{array}$ & 6 & 2300 & 836.8 & 1.046 \\
\hline
\end{tabular}

Table 8: W Doors - Solid Core Pine Timber Fig 24), U-value: 2.310 W/m².K

\begin{tabular}{llllll}
\hline $\begin{array}{l}\text { Sr. } \\
\text { No. }\end{array}$ & Layer name & $\begin{array}{l}\text { Width } \\
(\mathbf{m m})\end{array}$ & $\begin{array}{l}\text { Density } \\
\left(\mathbf{k g} / \mathbf{m}^{3}\right)\end{array}$ & $\begin{array}{l}\text { Specific Heat }(\mathbf{J} / \\
\mathbf{k g . K})\end{array}$ & $\begin{array}{l}\text { Thermal Conductivity } \\
(\mathbf{W} / \mathbf{m} . K)\end{array}$ \\
\hline 1 & $\begin{array}{l}\text { Wood Pine } \\
\text { with Grain }\end{array}$ & 40 & 550 & 2301 & 0.343 \\
\hline
\end{tabular}


Pahwa, P Sharma, A
The zone settings for calculating the Monthly Loads/Discomforts have been grouped together in the Fig 25. Results of the Monthly Heating and Cooling Loads of the most used zones viz Drawing Room, Dining Room, Kitchen and the Bedrooms have been shown in the following graph charts. (Figs. 26, 27, $28 \& 29$ )

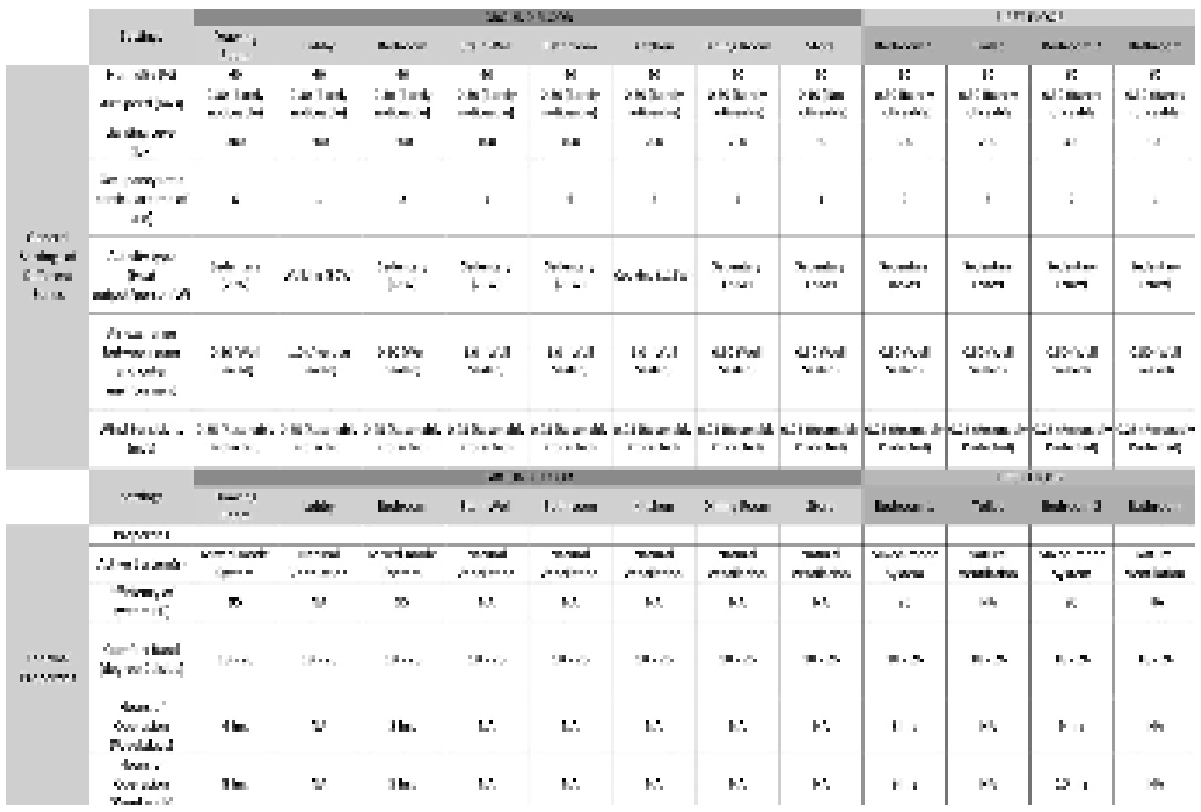

Figure 25: Zone settings for calculating the Monthly loads/Discomforts.

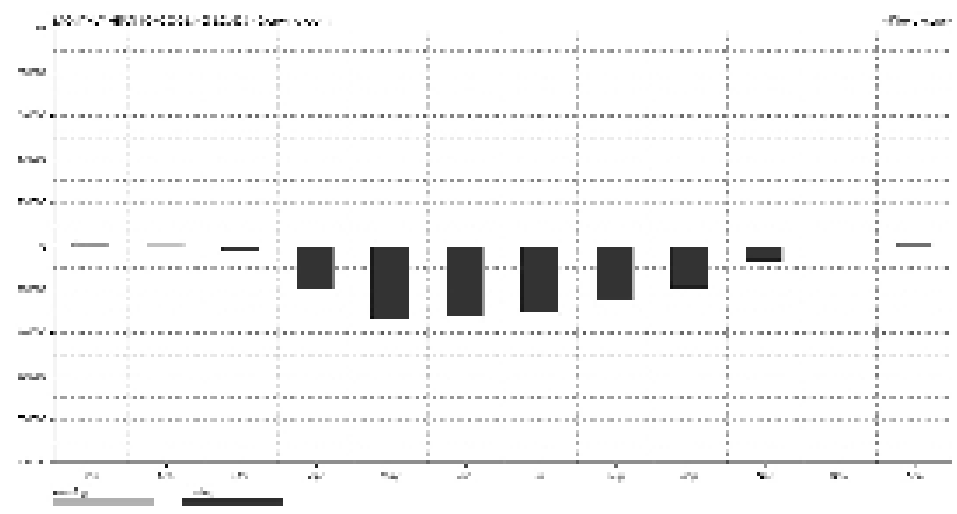

Figure 26: Monthly Heating and Cooling Loads in Drawing Room. 


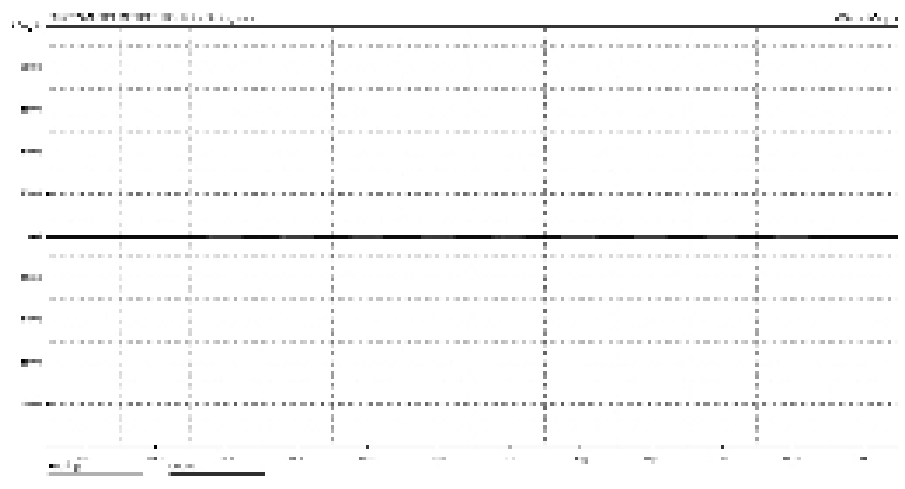

Increasing Life Span of Government Housings of Chandigarh - A

Need-Based

Approach to Retrofit Through Prototype Study of E-Type Housing

Figure 27: Monthly Heating and Cooling Loads in Dining Room.

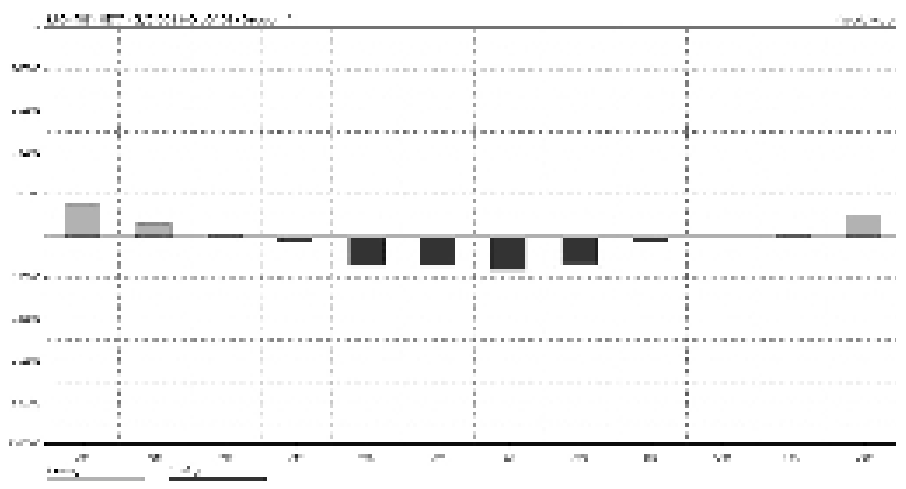

Figure 28: Monthly Heating and Cooling Loads in Bedroom 1.

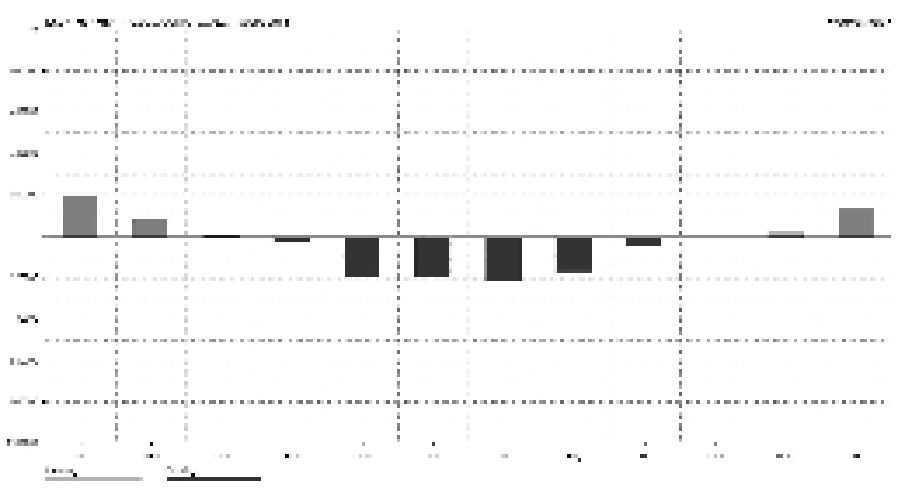

Figure 29: Monthly Heating and Cooling Loads in Bedroom 3. 
Pahwa, P Sharma, A

As one can see from the monthly power load charts above and the thermal comfort graphs below, the rooms tend to stay cool in winters and warm in summers, which does not present an ideal situation, and again adds on to the power consumption. The results indicate rather strongly that presently the passive techniques used in these low cost houses are not up to the standard that ought to be.

\section{CONCLUSION}

The entire evaluation and assessment procedure indicates the need to retrofit the given housing type with meticulous planning and research, lest either the architectural merit is lost or the ecological footprint of the buildings increases. To make things coherent, following pointers can be highlighted from the study:

- Green retrofit techniques would help conserve the embodied energy of the buildings.

- The building envelop must be modified to meet energy efficiency and climate responsiveness.

- Sizes and location of fenestrations should be more intrusive for wholebuilding lighting and ventilation.

Due to the short span of time available to finish this study, the research has been left with following limitations, which can be covered in further research by academicians and professionals:

- Only one housing-type out of the 14 typologies in Chandigarh could be analyzed. It bears mention that since different housing types were meant to serve people from different income groups (and still do), their construction and planning are varied. Thus, it is not entirely correct to specify the same generic retrofitting techniques and guidelines to all of these.

- Since the study is more architectural in nature, than structural, the structural techniques mentioned here are very basic and require better precision and case-sensitiveness. Hence another recommendation is to explore the structural part of the study.

\section{REFERENCES}

[1] BAHGA, S. and BAHGA, S. (2000) Le Corbusier and Pierre Jeanerette: Footprints on the Sands of Indian Architecture. New Delhi: Galgotia Publications.

[2] EVENSON, N. (1966) Chandigarh. Berkeley: University of California Press.

[3] GOYAL, J. (2005) BIS Codes on Earthquakes. The Tribune, 13th May. Available from: http://www.tribuneindia.com/2005/20050513/science.htm [Accessed: July 30, 2009]. 
[4] JACKSON, I. and HOLLAND, J. (2014) The Architecture of Edwin Maxwell Fry and Jane Drew: Twentieth Century Architecture, Pioneer Modernism and the Tropics. Surrey: Ashgate Publishing Limited.

[5] JOSHI, K. (1999) Documenting Chandigarh-The Indian Architecture of Pierre Jeanneret, E. Maxwell Fry, Jane B. Drew. Ahmedabad: Mapin Publications

[6] LE CORBUSIER (1958) Oeuvre complete 1952-1957. Zurich: Girsberger

[7] TOMAŽEVIČ, M. (2003) Structural assessment, monitoring and evaluation of existing masonry buildings in seismic regions. Proceedings of the International RILEM Workshop on On-Site Control and Non-Destructive Evaluation of Masonry Structures and Materials, Mantova, 12-14 November 2001. Bagneux: RILEM Publications, pp. 69-80

[8] WHAT CORBU HAS BEEN UP TO: BUILDING AN ENTIRE NEW CITY IN INDIA. (1953) Architectural Forum. September 1953, pp. 142-49.
Increasing Life Span of Government Housings of Chandigarh - A Need-Based Approach to Retrofit Through Prototype Study of E-Type Housing 